\title{
A Brief Overview on Conservation of Lakes in India
}

\author{
Rohini.A \\ CVR College of Engineering, H\&S Department, Hyderabad, India \\ Email: rohini.escience@gmail.com
}

\begin{abstract}
Aquatic ecosystem like lakes worldwide are being severely altered or destroyed at a rate greater than that any other times and far faster than they are being restored. This article focuses on the restoration and conservation measures to be followed for the management of lakes which are facing the problem of environmental degradation due to population explosion, urbanization, industrialization, discharge of domestic sewage, industrial effluents, chemical intensive agriculture, dumping of municipal solid waste, idol immersion etc. These measures should be strictly followed by the people and the government because lakes and their surroundings are unique assets and valuable ecosystems for both society and nature. Lakes have social, cultural, aesthetic and economic values and it is our responsibility to retain the glory and pristine beauty of the lakes.

Index terms-Lakes, Degradation of lakes, Urbanization, Eutrophication, Siltation, lake pollution, lake conservation, Dal lake, Hussain sagar lake.
\end{abstract}

\section{INTRODUCTION}

Water is the source of life on earth and earth is known as the 'Watery Planet' because it is the only planet in the solar system with the abundant source of water. About 97 percent of earth's total water supply lies in oceans which is unsuitable for human consumption due to its saline content, $2 \%$ percent is frozen in the polar ice caps and the remaining $1 \%$ percent is available in lakes, rivers and groundwater (Table 1) which is suitable for human consumption. Lakes are the best available fresh water resources on the earth's surface as we can freely access only the water in lakes. Lakes have traditionally served the function of meeting water requirements of the people for drinking, household uses like washing, for agriculture, for fishing and also for religious and cultural purposes. Apart from these functions, lakes are known to recharge ground water, controls runoff, moderate the hydrological events drought and floods, host variety of flora and fauna and provide a wide array of recreational activities and aesthetic benefits for humans to enjoy.

With rapid urbanization and expansion of city boundaries, a number of lakes in urban areas are facing issues of over exploitation, encroachment, pollution etc. Therefore, it is needed to initiate efforts to restore and conserve the lakes. TABLE 1

DISTRIBUTION OF WATER ON EARTH

\begin{tabular}{|c|c|}
\hline Water Source & Percentage of total water \\
\hline Oceans & 97.3 \\
\hline Glaciers and icecaps & 2.14 \\
\hline Ground water & 0.61 \\
\hline Lakes & 0.017 \\
\hline Rivers & 0.0001 \\
\hline Atmosphere & 0.001 \\
\hline
\end{tabular}

\section{CALSES FOR DEgRADATION OF LAKES}

For mankind, water is a basic need. It influences and alters the social, cultural, political and religious heritages of different communities. The need for plentiful supply of water is universally demanded. However, much importance is not given to the quality of water. All over the world, the first victims of water pollution are the water bodies like lakes so that even one time drinking water resources are facing the crisis. In the last half of the $20^{\text {th }}$ century, lakes underwent unprecedented environmental degradation. The major factors that lead to the degradation of lakes are

- Rapid urbanization and encroachment

- Continuous flow of untreated sewage

- Intensive agricultural runoff

- Discharge of industrial toxic effluents

- Dumping of debris and garbage

- Heavy siltation and pollution due to idol immersion.

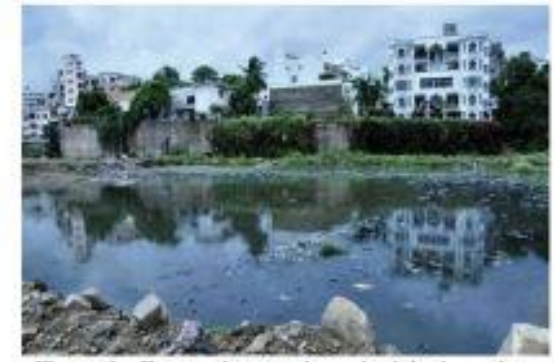

Figure. 1. Encroachment along the lake boundary

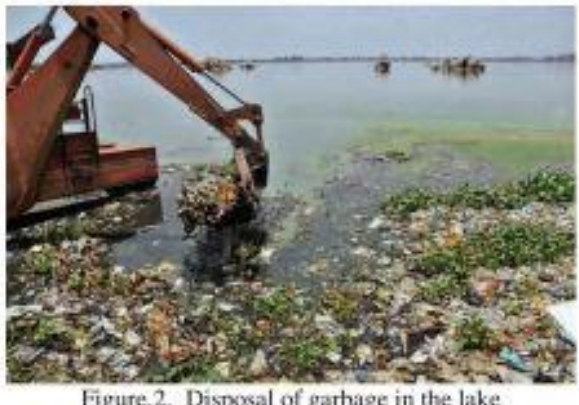

Figure, 2. Disposal of garbage in the lake

\section{IMPACT OF URBANIZATION ON LAKES}

Various problems are associated with urban water bodies. Human settlements and effluent geneses from various sources are the chief factors for the degradation of lakes. The anthropogenic pressure has also resulted in degradation due to deforestation, extensive agricultural use, flow of slit 
and harmful chemicals. The tourists who come for visiting the lakes pollute the lakes by throwing harmful waste and polythene bags. Increasing encroachment on the bank of the lakes causes deterioration of water quality and disturbs the biodiversity of the lake, all these cause an impact on climate change also.

Rapid urbanization has following impacts on lakes:

\section{A. Eutrophication}

Lakes in the urban areas receive enough nutrients like nitrates and phosphates from sewage, industrial effluents and fertilizer and pesticide rich run-off from agricultural fields which promote the rapid and lush growth of oxygen consuming algae especially blue-green algae and aquatic weeds like water hyacinth. This growth deoxygenates water and the depleted levels of oxygen in water leads to a situation where aquatic life forms cannot survive. The dead organisms undergo anaerobic decomposition releasing anoxic gases like methane, hydrogen sulphide and carbon dioxide which makes the lakes stink emitting foul smell. This process of nutrient enrichment of the lakes leading to excessive plant growth is called Eutrophication and the lakes are termed as Eutrophic lakes.

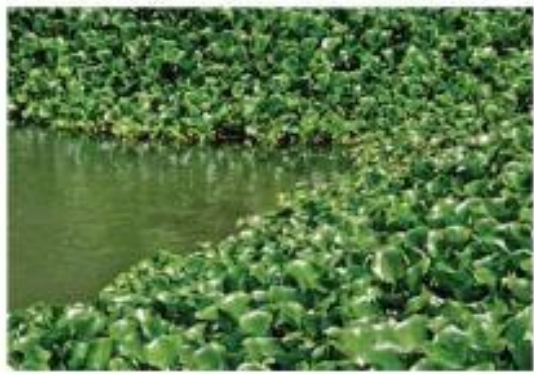

Figure. 3. Eutrophication infestation with water byacinths

\section{B. Siltation or Sedimentation}

Siltation is a form of water pollution where water flowing into the lakes brings sediment which is either silt or clay and settles at the bottom of the lakes. Activities like deforestation, intensive agricultural cultivation and land clearances for construction loosen the top soil. which finds its way into the lakes.

\section{LMPACT OF LAKE POLLUTION}

Lake pollution has the following effects:

\section{A. Toxic chemical effects}

Chemical toxic substances like heavy metals and pesticides in sewage, industrial effluents and agricultural run-off pollute the lakes affecting aquatic organisms and humans. Pesticides like DDT and heavy metals like lead, mercury and cadmium which are not water soluble are absorbed into the tissues of the organisms from the polluted water and accumulate in the organism's body, This process is called Bioaccumulation. The concentration of these toxic substances build up at successive levels of food chain. This process is called Biomagnification. These phenomena cause various types of diseases in humans effecting different body organs.

B. Water borne diseases
Waste water especially sewage that is discharged into lakes contain pathogenic (disease causing) organisms like bacteria, virus and parasites that are capable of transmitting water borne diseases in humans. Some of the water borne diseases are diarrhoea, cholera, typhoid, dysentery, jaundice, gastroenteritis etc.

\section{NEED FOR LAKe CONSERVATION}

Lakes when restored and conserved have the following environmental and ecological benefits:

- Harvest rainwater and recharge ground water.

- Reduce water logging and flood risk

- Increase economic activities through ecotourism and recreational activities.

- Enhance biodiversity in and around the lakes

- Improve the health conditions of the people living in the lake surroundings.

\section{LAKE CONSERVATION STRATEgIES}

A. Lake protection steps:

- Preventing encroachment of lake surroundings for different activities.

- The shore line of the lakes must be properly fenced to protect from encroachment.

B. Lake management steps:

- Construction of sewage treatment plants for treating sewage and letting the water into the lakes.

- Separating waste water from the storm water.

- The inlets and outlets of the lakes should be identified and need to be monitored at regular intervals.

- Encouraging management and handling of municipal solid waste.

- Beautification of lake bund by landscaping and plantation.

- Plantation on the lake surroundings to prevent soil erosion.

- Increasing community participation

- Reducing pollution through idol immersion by following Green Ganesha drive i.e., making use of environmentally friendly idols.

- Environmental education and awareness

C. Lake restoration steps:

- De-silting the lake bed by dredging

- De-weeding

- Removal of floating aquatic plant species.

\section{LEGAL FRAMEWORK FOR LAKE CONSERVATION IN INDIA}

The lakes and water bodies of India are directly influenced by a number of legal and regulatory frameworks. The fundamental duties enshrined in the constitution of India Article $51 \mathrm{~A}(\mathrm{~g})$ states "It shall be the duty of every citizen of India to protect and improve the natural environment 
including forests, lakes, rivers and wildlife and to have compassion for living creatures."

MoEF (Ministry of Environment and Forests) plays an important role in the restoration and conservation of lakes/water bodies in India. MoEF has implemented NLCP (National lake conservation plan) in 2001 for conservation and management of polluted and degraded lakes in urban areas. The major objectives of NLCP include encouraging and assisting state governments for sustainable management and conservation of lakes.

\section{Acts for the conservation of water bodies:}

- Water (Prevention and Control of Pollution) Act, 1974. This act was introduced to ensure domestic and industrial effluents are not allowed to discharge into water courses without adequate treatment. Contravention of this law will lead to punishment for a period not less than six years with fine.

- Environment Protection Act, 1986.This is an umbrella act under which the central government can notify steps to be taken by states for ensuring protection, conservation of the environment, including lakes and other bodies.

Authorities for consenvation of lakes:

- Ministry of environment and forests

- Ministry of water resources

- Agriculture ministry

- Other local authorities i.e. Municipal corporations, Water supply boards, Tourism department etc.

\section{Present Status Of Some Of The LaKes IN INDIA}

\section{A. Dal lake}

Dal lake, the jewel of Kashmir valley attracts a number of tourists due to its exotic natural scenic beauty and hundreds of house boats which facilitates tourists in enjoying the peace and tranquility of the whole Kashmir valley. Dal lake is one of the most beautiful lakes of the world and is a home for a variety of flora and fauna. However, this lake is suffering from problems like discharge of sewage and effluents which led to growth of aquatic weeds and water hyacinths due to eutrophication, dumping of garbage from hotels, human settlements, siltation and uncontrolled tourists pressure. A large number of commercial buildings including hotels, restaurants and house boats have reduced the size of the lake.

\section{Dal lake consenvation}

Under the National lake conservation plan of the Ministry of environment and forests of the Government of India, the restoration and rehabilitation measures undertaken to bring the lake to its original eutrophication free status are construction of siltation tanks, mechanical de-weeding, regrouping of house boats and reforestation of catchment area to reduce erosion and movement of silt.

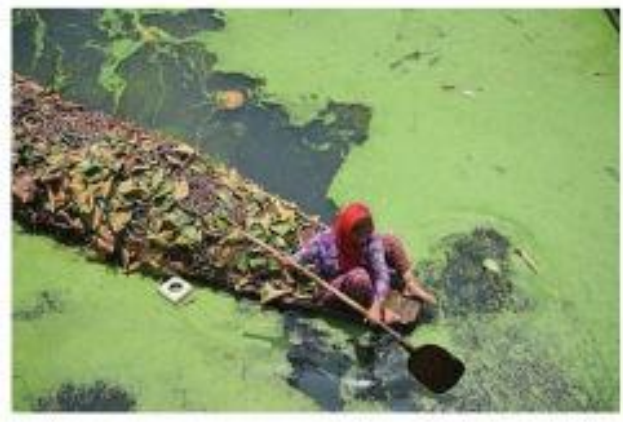

Figure.4. Excessive Eutrophication infestation by aquatic weeds in Dal Lake

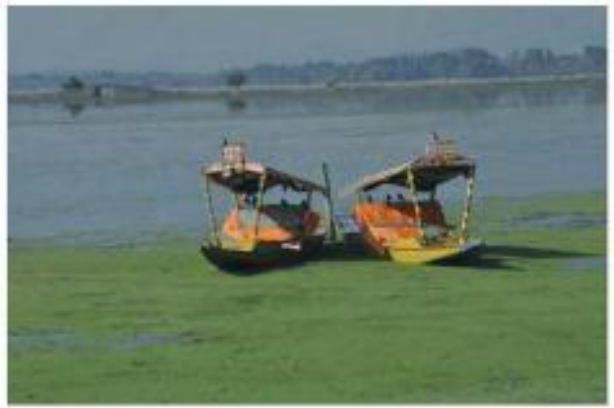

Figure.5. Eutrophic Dal lake with house boats

\section{B. Hussain sagar lake}

Population growth and industrialization lead to encroachments and shrinking of lakes in Hyderabad.The famous Hussain sagar was built during 1562 ( 450 years old) which served as a source of drinking water during the Nizam's time was completely polluted. In the last 30 years, the lake shrank more than $50 \%$ of its original size. The quality of water in the lake has gradually deteriorated mainly due to the continual entry of untreated domestic sewage and industrial effluents which is the reason for eutrophication. The other reasons of pollution are dumping of solid waste as well as immersion of large number of Ganesh and Durga idols during festivals.

\section{Impact of Idol immersion on lakes}

The traditional mud idols have been replaced by plaster of paris statues. Plaster of paris contains gypsum, phosphorus, sulphur and magnesium which do not degrade and forms an impermeable layer at the bottom of the lakes. Particularly, the colours used in making the idols contain the heavy metals mercury, lead and chromiumwhich are potential causes of developing cancer. These materials poison water bodies by increasing the chemical and organic load affecting the aquatic organisms in large numbers, blocking the natural flow of water and causing stagnation and siltation. Due to the concern raised by the environmentalists regarding the pollution of the lakes due to immersion of idols, environment friendly idol immersion is followed which can reduce the pollution load and restore the pristine beauty of the lakes. Immersion of idols in artificial ponds is 


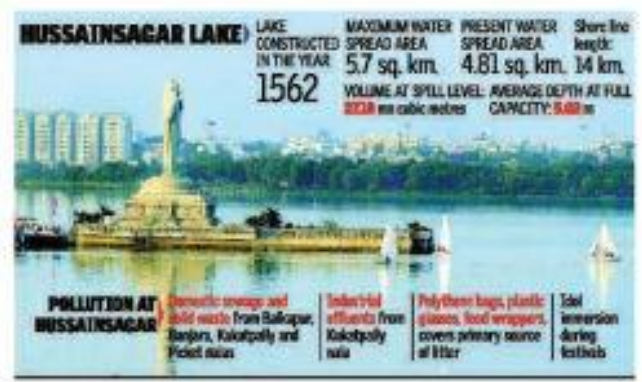

Figure.6. Pollution details of Hussain sagar lake

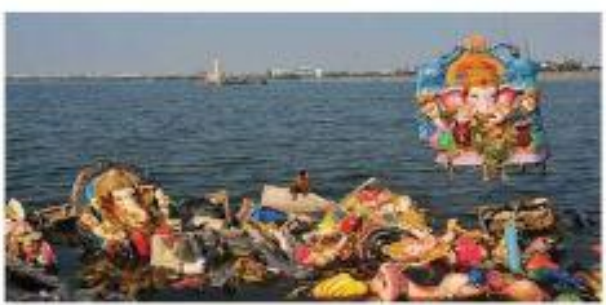

Figure.7. Immersion of idols during festivals in Hussain sagar lake

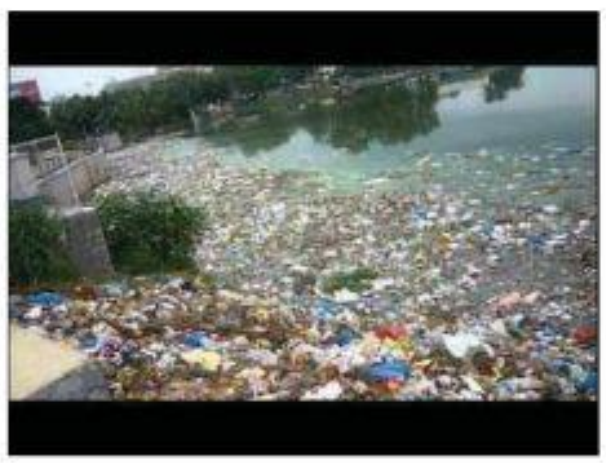

Figure,8. Disposal of solid waste in Hussain sagar lake

also one of the ways to reduce lake pollution. Artificial or temporary ponds are constructed near the surroundings of the lakes exclusively for immersion of idols. Continuous fresh water supply should be ensured into the ponds to avoid turbidity where the supernatant water overflows through the holes provided to the artificial pond.

\section{Hussain sagar lake conservation}

HMDA (Hyderabad metropolitan development authority) has started HCIP (Hussain sagar lake and catchment area improvement project) to improve the quality of Hussain sagar lake.

The following measures are being followed to improve the quality of the lake under HCIP.

\section{A. To prevent encroachment}

- Fencing and bund road formation

- Plantation on the surroundings

\section{B. To improve lake ecosystem}

- Installation of fountains to increase dissolved oxygen.

- Desilting by dredging

- Removal of aquatic weeds

C. To improve recreation activities

- Beautification around lake

- Discharge of treated water in the lake

D. To prevent lake pollution

- Setting of sewage treatment plants

- Organizing public awareness campaigns

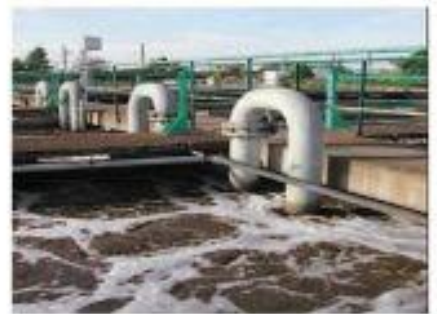

Figure 9, View of Sewage treatment plant at Hussain sagar lake

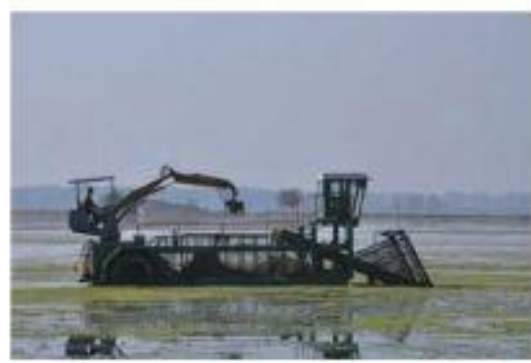

Figure.10. A Deweeding machine removing aquatic weeds

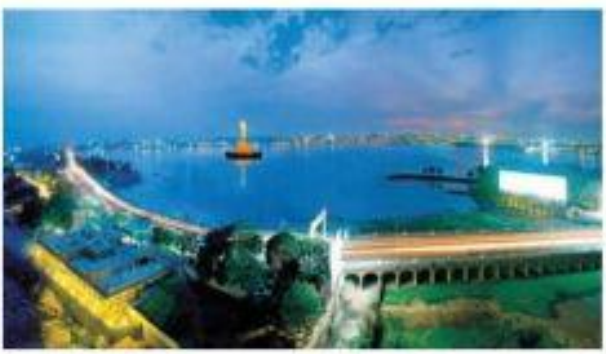

Figure.11, Beautification around Hussain sagar lake

\section{CONClusions And Suggestions}

Urban lakes or water bodies are the first victims of urbanization and their conservation is a sign of healthy and sustainable urban development. Lake conservation strategies if followed strictly by the government and the people will have environmental and ecological benefits. 
People should be made aware of importance of lakes and then the laws should be implemented for punishing those who pollute the lakes. There is also need of setting up courts dealing only with environmental issues. Nature has enriched us with a number of resources and it is our duty to do every possible thing to restore it. The same duty is recognized under Article 51 A ( $\mathrm{g}$ ) of constitution of India.

\section{REFERENCES}

[1] Ministry of urban development, GOI, 2013. Advisory on conservation and restoration of water bodies in urban areas, http: $/ /$ moud.gov.in

[2] MoEF, GOI, 2008. Guidelines for National lake conservation plan.

[3] Siddhartha Koduru and Swati Dutta, "Urban Ecosystems: Preservation and Management of urban water bodies," Creative space, Volume I, Number I, July, 2013.

[4] Takashi Asaeda, Jagath Manatunge, Tilak Priyadarshana and Bae Kyung Park, Saitama University, Japan, "Problems, restoration and conservation of lakes and rivers,"Oceans and aquatic ecosystems, Volume I.

[5] Gaurav Garwa and Govind Ram Meena, National academy of legal studies, Hyderabad, "Conservation of lakes: Legal solutions," Proceedings of Taal2007: The $12^{\text {th }}$ world lake conference: 1149-1153.

[6] Syeda Azeem Unnisa, Osmania University, Hyderabad, "A framework for conservation and restoration of water bodies," Review of research journal, Volume 3 , Issue 10, July 2014.

[7] Environmental Studies by Anubha Kaushik and C.P.Kaushik, New Age International Publishers, fourth edition, 2012.

[8] Environmental Studies by S.Deswal and A.Deswal. Dhanpat Rai and CO.(P) ltd., second edition, 2008.

[9] Nisha Kumari, Indian institute of science, Bangalore, "Status of lakes in Hyderabad,"2013.

[10] Environmental Studies by Dr. Syeda Azeem Unnisa, Frontline Publications, Edition 2011. 